\title{
Wisata Qur'an: Dakwah dan Wisata Edukatif Islami
}

\author{
Santi Susanti, Sukaesih \\ Fakultas Ilmu Komunikasi, Universitas Padjadjaran \\ santi.susanti@unpad.ac.id \\ sukaesih@unpad.ac.id
}

\begin{abstract}
This study aims to describe the emergence of the Qur'an Tourism destination and its relation to da'wah communication, which was initiated by Syaamil Quran, one of the Quran printing company in Bandung. This research uses a qualitative method with a case study approach. Data is collected through interviews, observations and documents and articles related to Quran Tourism and Syaamil Quran. The results of data processing show that Quran Tourism is an alternative form of tourism that acts as an Islamic da'wah to spread the goodness and noble value of the Qoran to the tour participants. In the Quran Tour, a guide leads participants to see the process of printing the Quran from the creative process to printing and ready to be distributed. After joining the tour, participants are expected to have a better understanding of the importance of the Quran so that they are encouraged to be closer to the Quran. The form of communication that occurs in the process of implementing the Quran Tourism is mostly verbal communication, through the delivery of information by the tour guide about the creative and printing processes..
\end{abstract}

Keywords: Qur'anic tourism, Da'wah communication, Al Qur'an printing, verbal communication.

\begin{abstract}
Abstrak
Penelitian ini bertujuan untuk memberikan gambaran mengenai kemunculan destinasi Wisata Qur'an yang diinisiasi oleh salah satu percetakan Al Quran di Bandung, Syaamil Quran, serta kaitannya dengan komunikasi dakwah.Penelitian ini menggunakan metode kualitatif dengan pendekatan studi kasus.Pengumpulan data dilakukan melalui wawancara, observasi serta dokumen dan artikel yang berkaitan dengan Wisata Quran dan Syaamil Quran.Hasil pengolahan data menunjukkan, Wisata Quran yang dilaksanakan oleh Syaamil Quran merupakan salah satu bentuk wisata alternatif yang berperan sebagai dakwah Islamiyah untuk menyebarkan kebaikan dan nilai luhur Al Quran kepada para peserta wisata.Dalam Wisata Quran, peserta diajak oleh pemandu untuk melihat proses pencetakan Al Quran dari proses kreatif hingga pencetakan dan siap didistribusikan. Selepas mengikuti wisata, diharapkan para peserta lebih memahami keutamaan Al Quran sehingga terdorong untuk lebih dekat dengan Al Quran.Bentuk komunikasi yang terjadi dalam proses pelaksanaan Wisata Quran didominasi oleh komunikasi secara lisan, melalui deskripsi informasi yang disampaikan pemandu wisata mengenai proses-proses yang berlangsung di area kreatif maupun area percetakan.
\end{abstract}

Kata kunci: Wisata Qur'an, komunikasi dakwah, pencetakan Al Qur'an, komunikasi lisan.

\section{Pendahuluan}

Al Qur'an merupakan kitab suci yang diturunkan oleh Allah Subhanahuwata'ala sebagai panduan bagi umat Islam untuk meraih kebahagiaan dalam hidup di dunia dan di akhirat. Setiap umat muslim akan berupaya untuk menjaga kemurnian isi Al Qur'an dengan 
selalu menelaahnya dan membacanya. Al Qur'an pun dikemas sedemikian rupa agar tampilannya menarik dan memudahkan setiap umat muslim untuk membacanya. Setiap umat muslim perlu ditumbuhkan kecintaannya kepada Al Qur'an, untuk meningkatkan keimanan dan menjadikan Al Qur'an benar-benar sebagai panduan, bukan sebagai pajangan.

Bandung, yang dikenal sebagai kota kreatif, senantiasa melahirkan beragam inovasi, yang dikemudikan hari menjadi penguat bagi julukan tersebut. Salah satunya dalam bidang pariwisata. Di antara sekian banyak jenis wisata yang ada, fashion, kuliner, budaya, taman, museum, dan lainnya, Kota Bandung memiliki satu lagi inovasi wisata berbasiskan religi, yakni Wisata Qur'an, yang diinisiasi oleh Syaamil Qur'an, salah satu perusahaan pencetakan Al-Qur'an yang berlokasi di kawasan Babakansari, Kiaracondong, Bandung. Syaamil Qur'an menjadikan perusahaannya sebagai destinasi Wisata Qur'an di Bandung yang dapat dikunjungi oleh masyarakat Kota Bandung khususnya, dan masyarakat dari mana pun yang ingin mengetahui proses menerbitkan $\mathrm{Al}$ Qur'an mulai dari proses awal perancangan content, hingga menjadi satu mushaf yang utuh.

Program Wisata Qur'an diresmikan Walikota Bandung, Ridwan Kamil, pada 5 Oktober 2013 di Pameran Buku Bandung di Landmard Convention Center, Jalan Braga 129 Bandung. Dalam sambutannya, walikota mengatakan, digagasnya Syaamil sebagai Pusat Destinasi Wisata Qur'an sejalan dengan program Pemerintah Kota Bandung, untuk menjadikan Kota Bandung sebagai pusat tujuan wisata yang beragam dan tematik

"Destinasi wisata tidak hanya pertokoan, tapi ke kampung-kampung. Dari kampung tematik di Kampung Dago Pojok yang khas dengan Kesundaan, Kampung Wayang di daerah Taman Hewan dan lain-lain. Juga pasar tematik mulai pasar Cihaurgeulis, pasar motor, pasar sepeda dan lainnya. Dengan demikian, ekonomi tersalurkan, kebanggaan, dan sebagainya,"

Adanya Wisata Qur'an, menurut walikota, dapat membangkitkan peluang ekonomi, dengan adanya Taman uQuran, yang akan melengkapi konsep taman tematik yang direncanakan oleh Pemkot Bandung.

Dalam tulisan ini, penulis memaparkan mengenai kemunculan destinasi Wisata Qur'an, serta kaitannya dengan komunikasi dakwah dalam menyebarkan kebaikan bagi sebanyak mungkin umat manusia.

\section{Metode Penelitian}

Tulisan ini berdasarkan hasil penelitian menggunakan metode kualitatif dengan pendekatan studi kasus deskriptif, untuk memaparkan kemunculan destinasi wisata Quran serta kaitannya dengan komunikasi da'wah.Studi kasus merupakan salah satu strategi dan metode analisis data kualitatif yang menekankan pada kasus-kasus khusus yang terjadi pada objek analisis (Bungin, 2011:237). Metode ini fokus pada kasus serta konteks yang dimiliki. Data penelitian diperoleh melalui wawancara kepada pengelola Wisata Quran, observasi, serta kajian pustaka yang terkait penelitian.

\section{Tentang Syaamil Qur'an}

Syaamil Qur'an merupakan unit penerbitan PT. Sygma Examedia Arkanleema yang menerbitkan Al Quran. Syaamil Qur'an memiliki tagline "Bersama Syaamil Qur'an, membaca dan memahami Al-Qur'an jadi mudah dan menyenangkan". Tagline ini menjadi misi yang diemban oleh Syaamil Qur'an untuk menerbitkan produk-produk yang memudahkan dan menyenangkan umat Isalam dalam membaca, mempelajari dan mendalami Al Qur'an. Untuk itu, Syaamil Qur'anmelakukan berbagai inovasi pada Al Quran yang diproduksinya, seperti 1) Al Quran yang yang sesuai segmentasi dan keperluannya2) Tata letak yang rapi 3) Menyertakan muatan keislaman, seperti asbabun nuzul, keutamaan surat, 
klasifikasi ayat-ayat Al-Qur'an, dan lainnya; 4) Al Quran interaktif yang dapat disuarakan melalui e-pen atau pena elektronik, yakni Al-Qur'an Miracle The Reference.5) Mushaf HajiUmrah yang dilengkapi barcodeberisi wawasan keislaman pada setiap halamannya yang bisa di-scan dan diakses menggunakan aplikasi mobile.

Produk-produk Syaamil Qur'an lainnya antara lain: Tikrar (Al-Qur'an Hafalan); Cordova (Al-Qur'an Terjemah); Hijaz (Al-Qur'an Terjemah Per Kata); Bukhara (Al-Qur'an Tajwid \& Terjemah); Azalia dan Yasmina (Seri Al-Qur'an Khusus Wanita); Mina (Al-Qur'an Tilawah); My First Al Qur'an (Qur'an untuk Anak)

Agar proses pencetakan selalu terjaga kesuciannya, digunakan bahan baku kertas Al Qur'an atau Qur'an Printing Paper (QPP) yang sudah mendapatkan sertifikasi Halal MUI. Selain itu, setiap karyawan yang bertugas di area percetakan diharuskan berada dalam kondisi berwudhu.

Prosesnya berlangsung terintegrasi, mulai dari pengembangan isi, pencetakan, sampai tahap akhir dengan mengedepankan adab-adab memuliakan Mushaf Al-Qur'an.Untuk mushaf yang akan didistribusikan ke seluruh Indonesia dan Asia Tenggara, isi Al Qur'anyang diterbitkan Syaamil mendapat jaminan tashih Kementrian Agama Republik Indonesia, Kementerian Dalam Negeri Malaysia, Pusat Dakwah Islam Brunei Darussalam. Selain itu, Syaamil Qur'an juga menjadi satu-satunya penerbit Al-Qur'andi Indonesia yang memiliki fasilitas percetakan sendiri dan mengintegrasikan aktivitas percetakannya dengan program ke-Qur'an-an bagi umat, melalui Wisata Qur'an, Gerakan \#AyoNgajiTiapHari, Wakaf 1 Juta Qur'an, Program Umroh Gratis untuk penghafal Qur'an, Training Menghafal Al-Qur'an, Training Menulis Al Quran, dan lainnya.

\section{Budaya Kerja Syaamil Qur'an}

Budaya kerja di Syaamil Quran dibangun secara islami, baik untuk lingkungan internal maupun alingkungan sekitar perusahaan. Dalam lingkungan internal, setiap harinya, karyawan diberi kesempatan untuk melaksanakan shalat dhuha serta tilawah Al Quran sebelum memulai pekerjaan. Selain itu, setiap karyawan diharuskan mengikuti kelompok baca Al Quran yang kegiatannya dilaksanakan setiap hari Jumat serta mengikuti pengajian bulanan yang menghadirkan penceramah khusus ke kantor Syaamil Quran.

Bagi lingkungan masyarakat, Syaamil Quran mengadakan program Wakaf Quran dan \#SemuaBisaNgaji. Program \#SemuaBisaNgaji merupakan pemberantasan buta huruf Al Quran tingkat desa yang dilaksanakan Syaamil Quran melalui pembelajaran selama 24 bulan atau tiga bulan kepada peserta yang tidak bisa membaca Al Quran sama sekali. Seluruh peralatan belajar, pengajar serta metode pengajarannya disipakan oleh Syaamil Quran.

\section{Sekilas Wisata Qur'an}

Wisata Quran adalah kunjungan ke Syaamil Quran untuk melihat secara langsung proses pencetakan Al Quran, mulai dari proses awal perancangan isi dan tata letak hingga proses produksi menjadi satu mushaf utuh yang siap untuk didistribusikan. Gagasan menjadikan Syaamil Quran sebagai Pusat Destinasi Wisata Qur'an di Kota Bandung, bertujuan mengenalkan nuansa agamis berwawasan Al Quran kepada masyarakat, serta menjadikan Bandung sebagai Kota Wisata Qur'an. Adanya program Wisata Quran ini diharapkan dapat memotivasi masyarakat untuk selalu berinteraksi dengan Al Quran. Seiring waktu, visi awal Wisata Quran yang menetapkan Syaamil Qur'an sebagai Pusat Destinasi Wisata di Kota Bandung, pada 2018 berubah menjadi Pusat Destinasi Wisata Qur'an di Indonesia.

Melalui upaya sinergis antara masyarakat dengan Pemerintah Kota Bandung diharapkan target Bandung sebagai kota kelas dunia, salah satunya sebagai kota destinasi 
Wisata Quran kelas dunia dapat terwujud. Target paling dekat adalah mewujudkan Kampung Quran untuk mendukung program Pemerintah Kota Bandung mendirikan kampung-kampung Tematik.

Selain Syaamil Quran, terdapat dua tempat lain yang dapat dikategorikan sebagai lokasi wisata Quran di Indonesia, yakni Bayt Al Quran dan Museum Istiqlal serta Desa Wisata Qur'an Hamasah. Keduanya memiliki ciri khas yang membedakannya dengan Syaamil Quran.

Bayt Al-Qur'anatau Rumah Al Quran dan Museum Istiqlal merupakan tempat wisata religi yang berlokasi di Jalan Raya Taman Mini Indonesia Indah, Pintu 1, Jakarta Timur. Bayt Al-Qur'andan Museum Istiqlal didirikan pada tahun 1994 atas ide Menteri Agama RI saat itu, Tarmizi Taher sebagai tempat menghimpun, menyimpan, memelihara dan memamerkan mushaf Al Quran dari berbagai macam bentuk dan jenis yang tersebar di seluruh nusantara. Ide mendirikan Bayt Al Quran tercetus dalam peresmian Mushaf Istiqlal, setahun setelah Presiden Soeharto menerima hadiah sebuah Al Quran besar dari Pondok Pesantren AlAsy’ariyah, Kalibeber, Wonosobo, Jawa Tengah.

Dalam Bayt Al-Qur'antersimpan koleksi Al Qur'an Manuskrip, Al Qur'an Cetakan, Al Qur'an Elektronik dan Digital, Terjemahan dan Tafsir Al Qur'an, serta Warisan Budaya Qur'ani (karya seni yang terinspirasi atau terkait dengan Al Qur'an). Sementara, koleksi yang terdapat di Museum Istiqlal mencakup manuskrip keagamaan, tekstil, arsitektur, nisan, seni rupa tradisional, dan seni rupa modern.

Sementara itu, Desa Wisata Qur'an Hamasah, yang berlokasi di kawasan Pantai Tanjung Tinggi, dan Lengkuas Island, Belitung, memfokuskan kegiatannya pada program 'Karantina 30 Juz Hafal Al Qur'an dalam 30 Hari'. Ini merupakan program berbayar yang besaran nominalnya dapat dipilih oleh calon peserta program.

\section{Kegiatan Wisata Qur'an}

Wisata Quran merupakan aktivitas wisata yang mobile. Terdiri dari tiga aktivitas utama, yakni pengenalan tentang sejarah Syaamil Quran dalam memenuhi kebutuhan Al Quran di masyarakat, yang disampaikan di dalam ruangan. Kemudian mengunjungi ruang kreatif tempat Al Qur'an dibuat. Terdiri dari tempat penyusunan dan layout naskah, desain dan proses quality control pemeriksaan khat/tulisan Al Qur'an dan ada pula proses pembuatan gambar kartun untuk dijadikan buku-buku cerita Islami. Pengunjung diberi kesempatan untuk bertanya langsung tentang proses kreatif penyusunan naskah kepada para kreatornya petugas yang ada di sana. Semua Al Quran yang akan dicetak, diproses menggunakan komputer grafis dengan penuh teliti.

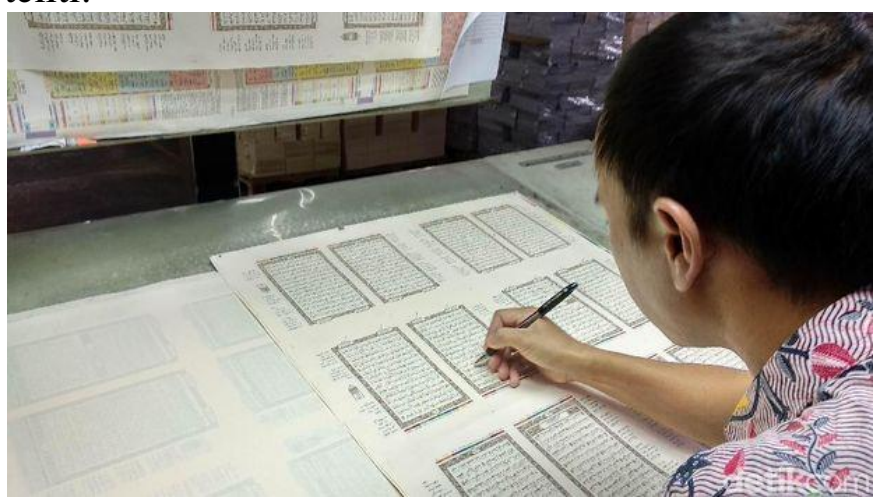

Pengecekan hasil cetakan Al Quran oleh petugas di bagian percetakan Syaamil Quran. (sumber: detikcom) 
Kunjungan berlanjut ke ruang produksi. Pengunjung bisa melihat proses produksi naskah Al Quran, mulai dari pencetakan, pelipatan, pembuatan cover, paching hingga menjadi satu mushaf utuh yang siap didistribisuikan ke seluruh wilayah Indonesia.

Untuk pencetakan, ada tiga mesin besar empat warna yang mencetak dengan kecepatan 9 ribu lembar per jam. Setiap seribu lembar, petugas memeriksa kerapian serta kesesuaian warna dan cetakannya.

Wisata Quran ke Syaamil ini berbeda dengan kunjungan ke percetakan Al Quran terbesar yang ada di Mina. Di sana, hanya wisatawan laki-laki yang diperbolehkan untuk melihat proses pembuatan Al Quran, itupun hanya sebatas di lantai 2 dan tidak diperbolehkan berinteraksi langsung dengan petugas. Sementara itu, pengunjung perempuan langsung diarahkan ke galeri hasil pencetakan Al Quran yang dilakukan di Mina.

\section{Kampung Wisata Al Quran: Edukasi tentang Al Quran}

Selain Wisata Al Quran, Syaamil pun mengelola Kampung Wisata Al Quran, yang diremikan pada 12 Agutus 2019, oleh Wakil Walikota Bandung, Yana Mulyana. Kampung Wisata Al Quran dibangun dengan tujuan memberikan edukasi tentang Al Quran kepada masyarakat, khususnya sekitar Kiaracondong. Adanya Kampung Wisata Al Quran ini merupakan bagian dari visi Bandung Agamis, yang dicanangkan Pemerintah Kota Bandung.

Kampung wisata ini merupakan hasil kolaborasi antara pemerintah setempat dengan Syaamil Quran untuk menumbuhkan minat baca Al Quran sehingga tercipta masyarakat yang tidak buta huruf Al Quran dan mencetak para hafiz Qur'an.

Program yang akan dijalankan di Kampung Wisata Al Quran, menurut Camat Kiaracondong, Rina Dewi, adalah memberikan edukasi tentang Al Quran, berupa belajar membaca hingga menghafal Al Quran.

"Kami ingin warga Kiaracondong bebas buta huruf Al Qur'an. Lahir pula penghafal Al-

Qur'an dan menghasilkan qari qariah terbaik untuk Kota Bandung,"

Kampung Wisata Al Quran akan dikembangkan di enam kelurahan di Kecamatan Kiaracondong. Adanya Kampung Wisata Al Quran ini diharapkan dapat mewujudkan Kiaracondong sebagai salah satu kampung tematik di Kota Bandung, yakni Kampung Agamis. Penataan infrastruktur pun akan dilakukan untuk menjadikan wilayah Kiaracondong, khususnya Babakan Sari, layak menjadi destinasi wisata.

Senada dengan Rina, Direktur Syaamil Quran, Riza Zacharias menjelaskan, salah satu program yang akan diberikan di Kampung Wisata Al Quran adalah cara membaca dan menghafal Al Qurnan bagi bapak-bapak berusia di atas 40 tahun. "Guru dan AlQur'annya kami siapkan. Setiap pekan mereka akan belajar dari nol."

\section{Wisata Quran sebagai Dakwah Islam}

Dakwah merupakan salah satu aktivitas penting dalam kehidupan umat Islam, terutama dalam penyebaran kebaikan ajaran Islam, baik kepada sesama muslim, maupun kepada sesama manusia. Dalam Al Quran, kata dakwah dan padanannya diulang sebanyak 321 kali (Muhyiddin, 2000: 20). Secara bahasa, dakwah, yang berasal dari bahasa Arab, diartikan sebagai panggilan, ajakan, atau seruan (Fakhruroji, 2017). Secara istilah, dakwah berarti mengajak orang lain meyakini dan mengamalkan akidah serta syariat Islam yang lebih dulu diyakini dan diamalkan oleh da'i (pendakwah) (Hasjmy (1994: 17). Asmuni Syukur (1983: 21) mengungkapkan, dakwah merupakan suatu usaha atau proses secara sadar dan terencana untuk mengajak manusia ke jalan Allah, memperbaiki situasi ke arah yang lebih baik dalam mencapai tujuan tertentu, yaitu hidup bahagia di dunia dan akhirat.

Sementara itu, SyukriadiSambas (1995: 38) memandang dakwah sebagai suatu proses panjang proses transmisi, transformasi dan internalisasi ajaran Islam menggunakan metode, 
media dan pesan yang disesuaikan dengan situasi dan kondisi objek dakwah, untuk mencapai tujuan tertentu.

Berdasarkan beberapa penjelasan tersebut, kegiatan Wisata Quran yang dilaksankan oleh Syaamil Quran dapat dikategorikan sebagai salah salah bentuk dakwah atau syiar agama yang dilakukan melalui kegiatan, yakni kegiatan Wisata Quran, yang melibatkan kelompok kecil sebagai peserta wisata. Dalam prakteknya, apa yang disampaikan pemandu wisata yang menerangkan mengenai keutamaan Al Quran, serta aktifitas yang berlangsung dalam proses pencetakan Al Quran merupakan bagian dari transmisi informasi kepada peserta melalui media lisan, yang penyampaiannya disesuaikan dengan usia peserta wisata, apakah anakanak, remaja, atau orang dewasa. Adapun tujuan yang ingin dicapai melalui penjelasan tersebut adalah membuka wawasan peserta wisata mengenai proses kreatif yang berlangsung dalam produksi Al Quran sehingga lebih menghargai dan menumbuhkan kecintaan kepada Al Quran sebagai petunjuk hidup bagi umat muslim dalam mencapai kebahagiaan di dunia dan akhirat, sebagaimana terdapat dalam Quran Surat Al Isra ayat 9, yang artinya. "Sesungguhnya Al-Qur'an ini memberikan petunjuk kepada (jalan) yang lebih lurus.. "(Q.S. Al Isra, 17:9).

Dakwah dapat dilakukan melalui berbagi cara. Enjang dan Aliyudin (2009: 12) menjelaskan, proses dakwah dapat dilakukan secara lisan, tulisan dan perbuatan serta aksi sosial lain seperti yang dicontohkan oleh Nabi Muhammad saw. Dakwah juga dapat dilakukan melalui lembaga dakwah yang mengelola kegiatan syiar Islam secara sistematis, terkoordinir melalui program yang terintegrasi dengan sumber daya yang tersedia untuk mencapai perubahan yang ditargetkan.

Berdasarkan hal ini, dapat disampaikan bahwa upaya yang dilakukan oleh Syaamil Quran dengan menerbitkan Al Quran dan buku-buku bertema Islami pun dapat dikategorikan sebagai dakwah, yakni dakwah bit-Tadwin, atau pola dakwah yang dilakukan melalui tulisan, baik dengan menerbitkan kitab-kitab, buku, majalah, internet, koran, hingga tulisan-tulisan yang mengandung pesan dakwah.

Wisata Quran yang dilakukan di Syaamil Quran dapat dikategorikan sebagai dakwah Fardiah; yang disampaikan kepada beberapa orang dalam jumlah kecil dan terbatas. Melalui metode deskripsi, pemandu wisata menjelaskan mengenai beberapa hal yang terkait dengan pencetakan Al Quran di Syaamil Quran. Dengan penjelasan yang disampaikan sekaligus melihat langsung proses pencetakan Al Quran diharapkan peserta wisata termotivasi untuk lebih mencintai Al Quran.

Metode lainnya dalam berdakwah, sebagaimana dipaparkan dalam Republika online adalah: Dakwah Ammah, yang dilakukan oleh seseorang kepada orang banyak secara lisan dalam bentuk khotbah (pidato); Dakwah bil-Lisan, yakni penyampaian informasi atau pesan dakwah melalui lisan secara langsung antara subyek dan obyek dakwah.Bentuk komunikasi ini dilakukan pula di Syaamil Quran melalui pemandu wista, yang menyampaikan penjelasan langsung secara lisan mengenai proses yang berlangsung di dalam pencetakan Al Quran.

Dakwah bil-Haal, dengan mengedepankan perbuatan nyata. Inilah yang dilakukan oleh Syaamil Quran melalui KampungWisata Al Quran yang dibangun bersama aparat pemerintahan di Kecamatan Kiaradong. Melalui berbagai kegiatan yang ditujukan keapda warga Kiaracondong, khususnya daerah Babakan Sari, berupa pemberantasan buta huruf Al Quran dan pembinaan untuk mencetak para penghafal Al Quran atau Hafiz, merupakan upaya nyata dalam menyebarkan kebaikan dari Al Quran yang diterapkan dengan menjadikan kawasan Babakan Sari sebagai kampung tematik di Kota Bandung.

\section{Kesimpulan}

Wisata Quran yang digagas oleh Syaamil Quran, perusahaan penerbit Al Quran dan buku-buku islami di Kota Bandung, merupakan wisata alternatif yang menawarkan nuansa 
baru dalam pariwisata di Indonesia, khususnya di Kota Bandung. Proses pencetakan Al Quran yang selama ini belum banyak diketahui oleh umat Islam sendiri, melalui wisata ini, setidaknya akan terbuka. Secara langsung peserta wisata ini dapat melihat proses yang selama ini bisa jadi tertutup, terutama bagi anak-anak dan perempuan. Karena, selama ini, proses pencetakan Al Quran yang berlangsung di Madinah pun tidak dapat dilihat secara dekat oleh umat muslim, terutama kaum ibu dan anak-anak. Hanya laki-laki yang dibolehkan untuk melihat langsung proses tersebut, itupun hanya dari lantai dua area percetakan, tidak bisa langsung melihat lokasi, apalagi berinteraksi dengan petugasnya.

Bentuk komunikasi yang terjadi dalam proses pelaksanaan Wisata Quran didominasi oleh komunikasi secara lisan, melalui deskripsi informasi yang disampaikan pemandu wisata mengenai proses-proses yang berlangsung di area kreatif maupun area percetakan. Bentuk lainnya adalah komunikasi interaktif antara peserta wisata dengan karyawan Syaamil Quran di area kreatif maupun area percetakan.

Adanya Kampung Wisata Al Quran, merupakan salah satu bentuk dakwah dalam bentuk perbuatan nyata, yang melengkapi proses penanaman kecintaan masyarakat kepada $\mathrm{Al}$ Quran yang digagas oleh Syaamil Quran. Melalui beragam kegiatan yang terdapat di dalamnya, yang terkait dengan Al Quran, diharapkan dapat menciptakan masyarakat muslim yang cinta Al Quran dan visi Bandung Kota Agamis dapat terwujud.

\section{DAFTAR PUSTAKA}

Bungin, Burhan. 2011. Penelitian Kualitatif. Edisi kedua. Jakarta. Kencana.

Enjang dan Aliyudin. 2009. Dasar-dasar Ilmu Dakwah. Bandung: Widya Padjadjaran.

Fakhruroji, Moch. 2017. Dakwah di Era Media Baru, Teori dan Aktivisme Dakwah di Internet. Bandung: Simbiosa Rekatama Media.

Hasjmy, A. 1994. Dustur Dakwah Menurut Al Quran. Jakarta: PT. Bulan Bintang.

Kemenag.go.id. 18 Agustus 2018. Berkunjung ke Percetakan AL Quran Raja Fahd di Madinah Al Munawarah. https://www2.kemenag.go.id/berita/85696/berkunjung-kepercetakan-al-quran-raja-fahd. Diakses 28 Agustus 2019.

Muhyiddin, Asep. 2014. Dakwah Perspektif Al Quran, dalm Kajian Dakwah Multiperspektif. Bandung: Remaja Rosdakarya.

Republika.co.id. 24 Februari 2017. 6 Metode Dakwah. https://www.republika.co.id/ berita/dunia-islam/islamnusantara/17/02/24/ olv2d3313-6-metode-dakwah. Diakses 28 Agustus 2019

Sambas, Syukriadi. 1995. Konstruksi Keilmuan Dakwah Islam Perspektif Filsafat Ilmu, Upaya Memahami dan Sosialisasi Pemberlakuan Kurikulum Nasional Fakultas Dakwah Tahun 1994. Bandung: Fakultas Dakwah IAIN Sunan Gunung Djati Bandung.

http://www.syaamilquran.com/tentang-kami 